\title{
Optical Properties of Lead Doped Titanium Oxide of Thin Films Prepared by Sol-Gel Method at Low Temperature
}

\author{
Fouzia. Abbas*, R. Bensaha \\ Ceramic Laboratory, University of Constantine 1, Algeria
}

Copyright $(2019$ by authors, all rights reserved. Authors agree that this article remains permanently open access under the terms of the Creative Commons Attribution License 4.0 International License

\begin{abstract}
The present paper reports on the structural and optical properties of undoped and $5 \% \mathrm{~Pb}$-doped $\mathrm{TiO}_{2}$ thin films deposited on glass and silicon substrates prepared by the sol-gel technique have been investigated. Dip-coated thin films have been examined at different annealing temperatures $\left(400-500{ }^{\circ} \mathrm{C}\right)$. The results shows that $\mathrm{Pb}$-doped $\mathrm{TiO}_{2}$ thin films start to crystallize at low temperature $\left(400{ }^{\circ} \mathrm{C}\right)$. The morphology and surface structure of the films were studied by scanning electron microscopy (SEM) and atomic force microscopy (AFM) reveals a nanoporous structure of anatase and brookite with particle sizes ranging between $20 \mathrm{~nm}$ and $100 \mathrm{~nm}$. Refractive index and porosity were calculated from the measured transmittance spectrum. SE study permits to determine the annealing temperature effect on the optical properties and the optical gap of the $\mathrm{Pb}$-doped $\mathrm{TiO}_{2}$ thin films. Photoluminescence (PL) spectrum revealed that emission increase with annealing temperature. A slight shift of transmission curves to higher wavelengths is observed for curves of $\mathrm{Pb}$-doped $\mathrm{TiO}_{2}$ thin films in comparison with those undoped, this was explained by the lowering of the band gap of $\mathrm{TiO}_{2}$.
\end{abstract}

Keywords Structural Properties, Optical Properties, $\mathrm{Pb}$-doped $\mathrm{TiO}_{2}$, Thin Films, Sol-Gel

\section{Introduction}

Titania nanocrystalline films has been extensively studied because of its unique properties and wide verity of applications such as dielectric materials, planar waveguides, gas sensors, electrochromic systems, dye-sensitive solar cells and photocatalysts [1-4].Titanium dioxide $\left(\mathrm{TiO}_{2}\right)$ has been widely used because of its attractive properties; such as a the high band gap, transparent in the visible range, high refractive index, high dielectric constant, and ability to be easily doped with active ions. It is important to note that this material is non toxic with a high band gap semiconductor $(3,2 \mathrm{eV})$ insensitive to visible light and it absorbs in the near ultraviolet region [5]. $\mathrm{TiO}_{2}$ crystallizes in three polymorphic forms: anatase (tetragonal), rutile (tetragonal) and brookite (orthorhombic). The anatase phase has been reported to develop at temperatures below $800{ }^{\circ} \mathrm{C}$, which at higher temperatures transforms to the more stable rutile phase. The occurrence of crystalline phase depends upon the deposition method, composition, density and annealing temperature. Legrand-Buscema et al. [6] reported that annealing the $\mathrm{TiO}_{2}$ films in $400-700^{\circ} \mathrm{C}$ temperature range exhibit anatase phase, however the annealing temperature beyond $800^{\circ} \mathrm{C}$ gives us a combination of rutile and anatase structure. The photocatalytic activity of $\mathrm{TiO}_{2}$ has been found to vary with its structural form and is reportedly higher in the anatase compared to the rutile $[7,8]$.

Additions of another semiconductor have been used to improve the properties of titanium dioxide. In principle, the coupling of different semiconductor oxides seems useful in order to achieve a higher photocatalytic activity [9]. Various composites formed by $\mathrm{TiO}_{2}$ and other inorganic oxides such as $\mathrm{SiO}_{2}$ [10], $\mathrm{ZnO}$ [11], $\mathrm{MgO}$ [12], $\mathrm{ZrO}_{2}$ [13], $\mathrm{PbO}[14,15]$, and so dopants like Fe, $\mathrm{Zn}, \mathrm{Au}, \mathrm{Ag}, \mathrm{Pb}$ [16-20] have been reported. The above cited studies show that doping metal ions into $\mathrm{TiO}_{2}$ could extend the light absorption from UV to the visible region, leading to the improvement of the photon response of $\mathrm{TiO}_{2}$ by introducing additional energy levels within the band gap of $\mathrm{TiO}_{2}$. K.M. Krishna et al. have studied optical and structural properties of $\mathrm{Pb}$-doped $\mathrm{TiO}_{2}$ thin films deposited by sol-gel dip coating technique. They have observed that the refractive index increases with increasing annealing temperature up to $500^{\circ} \mathrm{C}$ [21]. S.D. Cheng et al. have observed that $\mathrm{Pb}$-doped $\mathrm{TiO}_{2}$ films prepared by sol-gel technique annealed at $500^{\circ} \mathrm{C}$ are 
highly transparent and can support several waveguide modes. Up to date, there have been a number of studies on the preparation of $\mathrm{Pb}$ doped $\mathrm{TiO}_{2}$ thin films [22]. Zeng et al. have prepared nanocrystalline lead titanate $\left(\mathrm{Pb}\right.$ doped $\left.\mathrm{TiO}_{2}\right)$ by an accelerated sol-gel process at $550^{\circ} \mathrm{C}$ [23]. Some lead titanate thin films are prepared at an annealing temperatures usually higher than $550^{\circ} \mathrm{C}$ [24], and sometimes in the temperatures range $650-800^{\circ} \mathrm{C}$ [25].

$\mathrm{TiO}_{2}$ films have been prepared by many deposition techniques such as metal-organic chemical vapor deposition (MOCVD) [26], electron-beam evaporation [27], pulsed laser deposition [28] and reactive sputtering technique [29]. Among these methods, sol-gel technique is the simplest one and the less expensive (low power consumption), this process is generally used by dip coating or spin coating $[30,31]$. Recently, $\mathrm{Pb}$-doped $\mathrm{TiO}_{2}$ thin films prepared by sol-gel method, exhibits many advantages like chemical stability, mechanical strength, high resistivity, high permittivity, these properties make this material a good candidate for use in the opto-electronic industry. However, Stiochiometric lead titanates have been prepared using sol-gel method by several authors with various precursors such as lead acetate trihydrate, $\mathrm{Pb}\left(\mathrm{CH}_{3} \mathrm{COO}\right)_{2} \cdot 3 \mathrm{H}_{2} \mathrm{O}$, and titanium tri-isopropoxide mono-acetylacetonate, $\mathrm{Ti}\left(\mathrm{C}_{3} \mathrm{H}_{7} \mathrm{O}\right)_{3}\left(\mathrm{CH}_{3}-\mathrm{COCHCOCH}_{3}\right)$, which had been reported to give good stability and better control of viscosity [32-35]. M. Rahman et al. instead the lead nitrate, $\mathrm{Pb}\left(\mathrm{NO}_{3}\right)_{2}$ and titanium tetra-isopropoxide $\mathrm{Ti}\left(\mathrm{C}_{3} \mathrm{H}_{7} \mathrm{O}\right)_{4}$ as the source materials for $\mathrm{Pb}$ and $\mathrm{Ti}$, respectively [36]. Studies of $\mathrm{Pb}$-doped $\mathrm{TiO}_{2}$ thin films have focused on their properties for use as optoelectronic devices such as solar cells, non-volatile memories $[37,38]$ and pyroelectric devices [39]. However, little attention has been paid on their applications in optical coatings at low temperature. $\mathrm{Pb}$ doped $\mathrm{TiO}_{2}$ thin films has been successfully prepared in our laboratory by sol gel dip-coating using tetrabutyl-orthotitanate $\left(\mathrm{C}_{4} \mathrm{H}_{9} \mathrm{O}\right)_{4} \mathrm{Ti}$ and lead acetate trihydrate $\left.\left(\mathrm{C}_{2} \mathrm{H}_{3} \mathrm{O}_{2}\right)_{2} \cdot 3 \mathrm{H}_{2} \mathrm{O}\right)$ as precursors.

This work is a continuation of our previous papers that has been done on structural, thermal and optical properties of undoped titanium oxide $\left(\mathrm{TiO}_{2}\right)$ reported by Bensaha [40, 41]. Further, Bensouyad et al. [11, 13] shows that the addition of $5 \% \mathrm{ZnO}$ or $5 \% \mathrm{ZrO}_{2}$ in $\mathrm{TiO}_{2}$ would be largely sufficient to crystallize the xerogels in anatase form by contrast to that of undoped $\mathrm{TiO}_{2}$. However, thin films obtained from annealing at $350{ }^{\circ} \mathrm{C}$ crystallize in both anatase and brookite phases.

In this paper, we will report the effect of doping with lead on structural and optical properties of $\mathrm{TiO}_{2}$ thin films deposited by the sol-gel dip-coating process at low temperature. Several experimental techniques were used to characterize structural and optical properties resulting from different annealing treatments and different layer thicknesses: X-ray diffraction, Raman spectroscopy, Scanning Electron Microscopy (SEM), Atomic Force Microscopy (AFM), Ellipsometry spectroscopy,
UV-visible and photoluminescence spectroscopy.

\section{Materials and Methods}

\subsection{Preparation of $\mathrm{TiO}_{2}$ sol}

The procedure of preparation includes the dissolution of $1 \mathrm{~mol}$ of butanol $\left(\mathrm{C}_{4} \mathrm{H}_{9} \mathrm{OH}\right)$ as solvent and 4 mol of acetic acid $\left(\mathrm{C}_{2} \mathrm{H}_{4} \mathrm{O}_{2}\right), 1 \mathrm{~mol}$ of distilled water is added as well as $1 \mathrm{~mol}$ of tetrabutyl-orthotitanate $\left(\mathrm{C}_{4} \mathrm{H}_{9} \mathrm{O}\right)_{4} \mathrm{Ti}$. In the second step, the solution of $\mathrm{Pb}$ was prepared fromthe dissolution of $1 \mathrm{~mol}$ of lead acetate $\left.\left(\mathrm{C}_{2} \mathrm{H}_{3} \mathrm{O}_{2}\right)_{2}+3 \mathrm{H}_{2} \mathrm{O}\right)$ as precursor in $2 \mathrm{~mol}$ of acetic acid as catalyst. The concentration of the $\mathrm{Pb}$ ions is $\mathrm{x}=5 \%$ at., which is defined as $\mathrm{x}=[\mathrm{Pb} /(\mathrm{Ti}+\mathrm{Pb})] \mathrm{x} 100$. Subsequently, $5 \%$ at. $\mathrm{Pb}$ contained solutions was added into the $\mathrm{TiO}_{2}$ sols.

\subsection{Preparation of $\mathrm{TiO}_{2}$ thin film}

After stirring at room temperature for $24 \mathrm{~h}$, the $5 \%$ $\mathrm{Pb}$-doped $\mathrm{TiO}_{2}$ sols were dip-coated on cleaned and dried silicon and glass substrates (refractive index 1.517 and thickness of glass layers is $20^{\circ} \mathrm{A}$ ) with a dip-coating apparatus made in our laboratory. The substrates were dip-coated in the solutions at a constant rate of $6.25 \mathrm{~cm} \mathrm{~s}^{-1}$. After each dipping, thin films were dried for $30 \mathrm{~min}$ at a distance of $40 \mathrm{~cm}$ from a 500 Wight source. The drying temperature of the light source is approximately equal to $100{ }^{\circ} \mathrm{C}$. Subsequently, thin films were heat treated in the temperature range $400-500^{\circ} \mathrm{C}$ using a heating rate of $5^{\circ} \mathrm{C}$ $\min ^{-1}$ for $2 \mathrm{~h}$ in furnace.

\subsection{Characterization}

X-ray diffraction was performed by Siemens D5005 diffractometer, using a $\mathrm{CuK}_{\alpha}$ radiation. The patterns were scanned at room temperature, over the angular range 10$70^{\circ} 2 \mathrm{~h}$, with a step length of $0.1^{\circ} 2 \mathrm{~h}$ and counting time of 1 s step $^{-1}$. Raman spectra were recorded in a back scattering configuration using a Jobin Yvon micro Raman spectrometer coupled to a DX40 Olympus microscope. The samples of doped and undoped $\mathrm{TiO}_{2}$ thin films were excited with a wavelength $532.8 \mathrm{~nm}$ with an output of 20 Mw. Optical properties of the films deposited on different (glass and silicon) substrates were examined by a UVVIS spectrophotometer (JASCO V-570). Morphological study was performed using scanning electron microscopy (SEM Philip XL-40 FEG) and atomic force microscopy (AFM) in tapping mode configuration by a Topometrix TMX 2000 Explorer AFM. Spectroscopic ellipsometry (SE) experiment was performed at room temperature using an automatic ellipsometer SOPRA GES5. The system uses a $75-\mathrm{W}$ xenon lamp, a rotating polarizer, an autotracking analyser, a double monochromator, a photomultiplier tube and a GaInAs photodiode as 
detectors. Data were collected in the $0.25-1.5 \mu \mathrm{m}$ region with the step of $0.005 \mu \mathrm{m}$, at incidence angle of $\theta=70^{\circ}$. The photoluminescence (PL) measurements were carried out using the Jobin Yvon-Spex make Spectrofluorometer (Fluorolog version-3; Model FL3-11) with 450W high-pressure xenon arc lamp as excitation source. PL excitation and emission spectra were acquired at room temperature for a spectral resolution of $0.2 \mathrm{~nm}$ and slit width of $0.25 \mathrm{~mm}$.

\section{Results and discussion}

\subsection{Structural properties}

\subsubsection{Crystalline phases (XRD, Raman)}

Fig. 1 shows XRD pattern of both undoped and $\mathrm{Pb}$-doped thin film obtained after 4 dippings and various annealing temperatures at 400,450 and $500^{\circ} \mathrm{C}$. Clearly, titanium oxide starts to crystallize at low temperature $\left(400^{\circ} \mathrm{C}\right)$. Furthermore, all XRD pattern show a peak corresponding to (101) plane which is attributed to nanocrystalline of anatase whatever the annealing temperature. In addition to anatase phase, the presence of brookite can be observed, it crystallizes with (121) plane. However, K. M. Krishna et al find that the films have amorphous/nanocrystalline nature with the presence of pure anatase at $550^{\circ} \mathrm{C}$ and anatase-rutile mixture as the temperature increases to $850^{\circ} \mathrm{C}$ [21],but M.M. Rahman et al shows that the doped films with different concentration $(5 \%, 10 \%$ and $15 \% \mathrm{~Pb})$ have amorphous/nanocrystalline nature at $550^{\circ} \mathrm{C}$ [36]. Peak intensities corresponding to characteristic planes of anatase and brookite phases are obviously increased with the increase of annealing temperature. The latter is probably due not only to the increase of proportion of titanium oxide but also to the improvement of the crystalline quality.

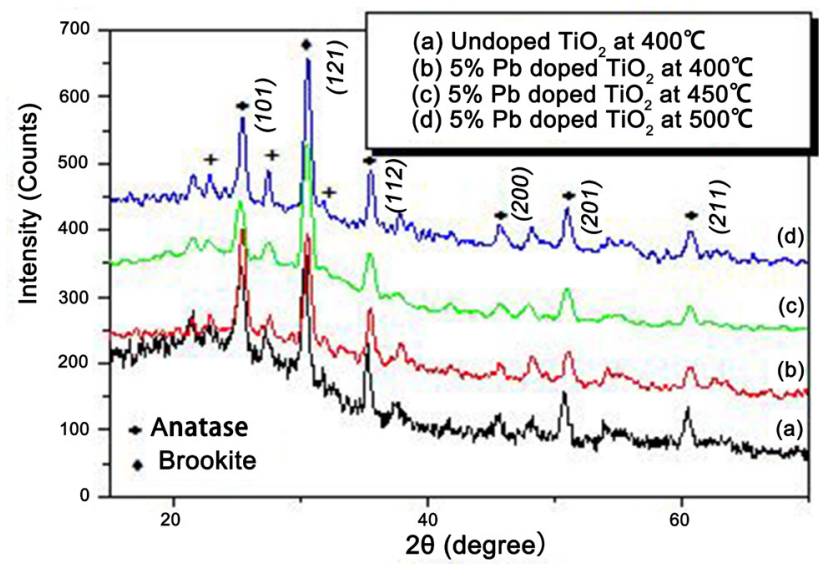

Figure1. Evolution of diffraction patterns of 5 at. $\% \mathrm{~Pb}$ doped $\mathrm{TiO}_{2}$ thin films; obtained at various annealing temperatures $\left(400{ }^{\circ} \mathrm{C}(\mathrm{a}), 450^{\circ} \mathrm{C}(\mathrm{b})\right.$, $\left.500^{\circ} \mathrm{C}(\mathrm{c})\right)$ for the same thickness

\subsubsection{Surface morphology and grain size}

The crystallite size $\mathrm{D}$ of $\mathrm{TiO}_{2}$ thin films doped with $\mathrm{Pb}$ can be deduced from XRD line broadening using the Scherrer equation [42]:

$$
\mathrm{D}=\frac{0,94 \mathrm{X} \lambda}{\sqrt{\left(\Delta_{\mathrm{hkl}}^{2}-\Delta_{\text {instr }}^{2}\right)}} \frac{1}{\cos \theta}(1)
$$

$\lambda$ is the wavelength of X-ray beam $\left(\mathrm{Cu} \mathrm{K}_{\alpha}=1.5406 \AA\right), \Delta_{\mathrm{hkl}}$ is the full width at half maximum (FWHM) of (hkl) diffraction peak, $\Delta_{\text {instr }}$ is the FWHM corresponding to the instrumental limit, and $\theta$ is the Bragg angle.

The computed values of grain sizes, given in Table.1, were calculated for different temperatures of annealing with the same thickness. Thus, the obtained grain sizes for intense peaks of anatase and brookite increase from 16, 22 $\mathrm{nm}$ to $18,53 \mathrm{~nm}$ and from 18,22 to $20,74 \mathrm{~nm}$, respectively. In fact, as the annealing temperature increases the grain size also increase and doping with the $\mathrm{Pb}$ increases the crystallite size compared to the undoped one.

Table.1. Structural parameters of $\mathrm{TiO}_{2}$ Thin Films Undoped and Doped with 5\% at.Pb, for Different Annealing Temperatures.

\begin{tabular}{cccccc}
\hline & & Phase & L (nm) & (hkl) \\
\hline Undoped $\mathrm{TiO}_{2}$ & $\begin{array}{c}\text { Thin films } \\
\text { Same thickness }\end{array}$ & $\begin{array}{c}\text { Annealed at } \\
400^{\circ} \mathrm{C}\end{array}$ & Anatase & 17,47 & $(101)$ \\
\hline $\mathbf{5 \%} \mathbf{P b}$ doped $\mathrm{TiO}_{2}$ & $\begin{array}{c}\text { Thin films } \\
\text { Same thickness }\end{array}$ & $\begin{array}{c}\text { Annealed at } \\
400^{\circ} \mathrm{C}\end{array}$ & Anatase & 18,02 & $(101)$ \\
& Annealed at & Brookite & 19,49 & $(121)$ \\
& $450^{\circ} \mathrm{C}$ & Anatase & 18,42 & $(101)$ \\
& Annealed at & Anatase & 18,53 & $(121)$ \\
& $500^{\circ} \mathrm{C}$ & Brookite & 20,74 & $(101)$ \\
\hline
\end{tabular}

Fig. 2 shows the Raman spectra in the range $100-900 \mathrm{~cm}^{-1}$ of the $\mathrm{Pb}$ doped $\mathrm{TiO}_{2}$ and undoped films grown on silicon substrates, annealed at the following temperatures 400,450 and $500^{\circ} \mathrm{C}$. The (a), (b), (c) and (d) spectra show symmetric vibration modes: $A_{1 \mathrm{~g}}+2 \mathrm{~B}_{1 \mathrm{~g}}+3 \mathrm{E}_{\mathrm{g}}$ of tetragonal anatase phase identified at $144 \mathrm{~cm}^{-1}\left(\mathrm{E}_{\mathrm{g}}\right), 197 \mathrm{~cm}^{-1}\left(\mathrm{E}_{\mathrm{g}}\right), 397 \mathrm{~cm}^{-1}\left(\mathrm{~B}_{1 \mathrm{~g}}\right)$, $435 \mathrm{~cm}^{-1}\left(\mathrm{~B}_{1 \mathrm{~g}}\right)$, and $638 \mathrm{~cm}^{-1}\left(\mathrm{E}_{\mathrm{g}}\right)$. The band positions are in good agreement with previous work for the anatase phase [43]. These bands can be assigned to anatase phase except the band $302 \mathrm{~cm}^{-1}$, which is due to the crystallization of brookite phase. While the bands at 144, 197 and $638 \mathrm{~cm}^{-1}$ can be assigned to both anatase and brookite phases [44, 45]. A 


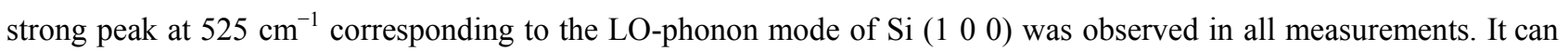
be seen that the intense Raman peak corresponding to the $\mathrm{E}_{\mathrm{g}}$ mode of $\mathrm{TiO}_{2}$ shifted towards higher wavenumbers. This shift can be attributed to the quantum confinement effect of $\mathrm{TiO}_{2}$ nanoparticules [46, 47]. No other peaks corresponding to doped samples have been observed in the spectra, which confirm the XRD results.

The absence of the characteristic lead vibration modes in the Raman spectra reveals that there is no segregation of that material into $\mathrm{TiO}_{2}$. This indicates that doping with lead may occupy the substitutional sites in the host lattice.

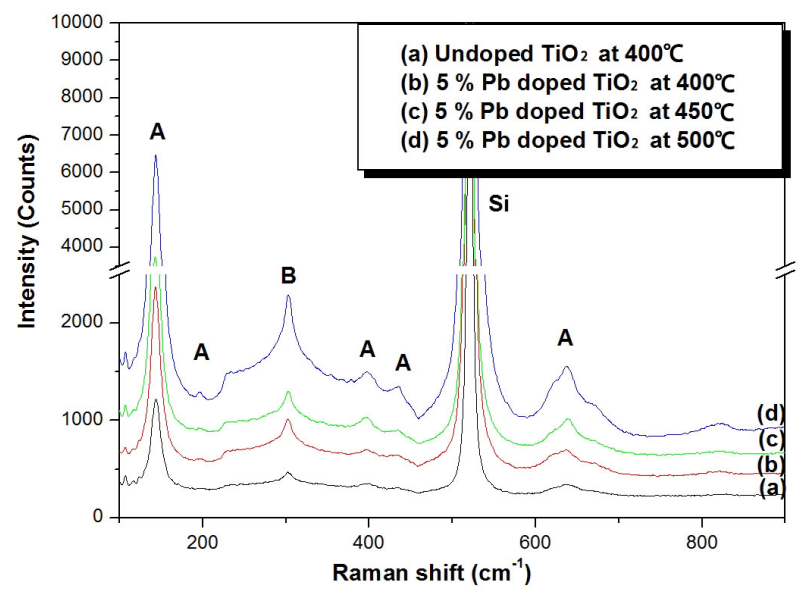

Figure2. Raman Spectrum of $5 \%$ at. $\mathrm{Pb}$ doped $\mathrm{TiO}_{2}$ Thin Films Annealing at Various Temperatures : $\left(400^{\circ} \mathrm{C}(\mathrm{a}), 450^{\circ} \mathrm{C}(\mathrm{b}), 500^{\circ} \mathrm{C}(\mathrm{c})\right)$; $\mathrm{A}=$ anatase, $\mathrm{Si}$ = substrate

\subsubsection{Surface morphology}

SEM micrographs, Fig.3 undoped and doped $\mathrm{TiO}_{2}$ Fig.3 (a-c) show the surface morphology of pure and Pb-doped $\mathrm{TiO}_{2}$ thin films deposited at various temperatures. These micrographs reveal the nanocrystalline nanoporous morphology with certain degree of agglomeration and an average particle size ranging from 20 to $100 \mathrm{~nm}$. Also, an increase in crystal size and crystallization of the films has been observed with increasing temperature, which is in agreement with XRD results. At the initial stages, the grain shape is spherical, but as the annealing temperature increases, crystallization with crystals of clear elongated needle-shape have been observed (micrograph (c) for $500^{\circ} \mathrm{C}$ ). This is due to an increase in surface mobility with increasing temperature, thus allowing the films to lower its total energy by growth of grains and decrease of grain boundary area. Moreover, as the temperature increases, the presence of two kinds (small and bulky) of crystallites were noticed (micrograph (b) for both $450^{\circ} \mathrm{C}$ and $\quad$ (c) $500^{\circ} \mathrm{C}$ ), which further supports the existence of mixed phases as also envisaged by XRD analysis (pattern (b) and (c) for both $450^{\circ} \mathrm{C}$ and $500^{\circ} \mathrm{C}$ in Fig. 1).
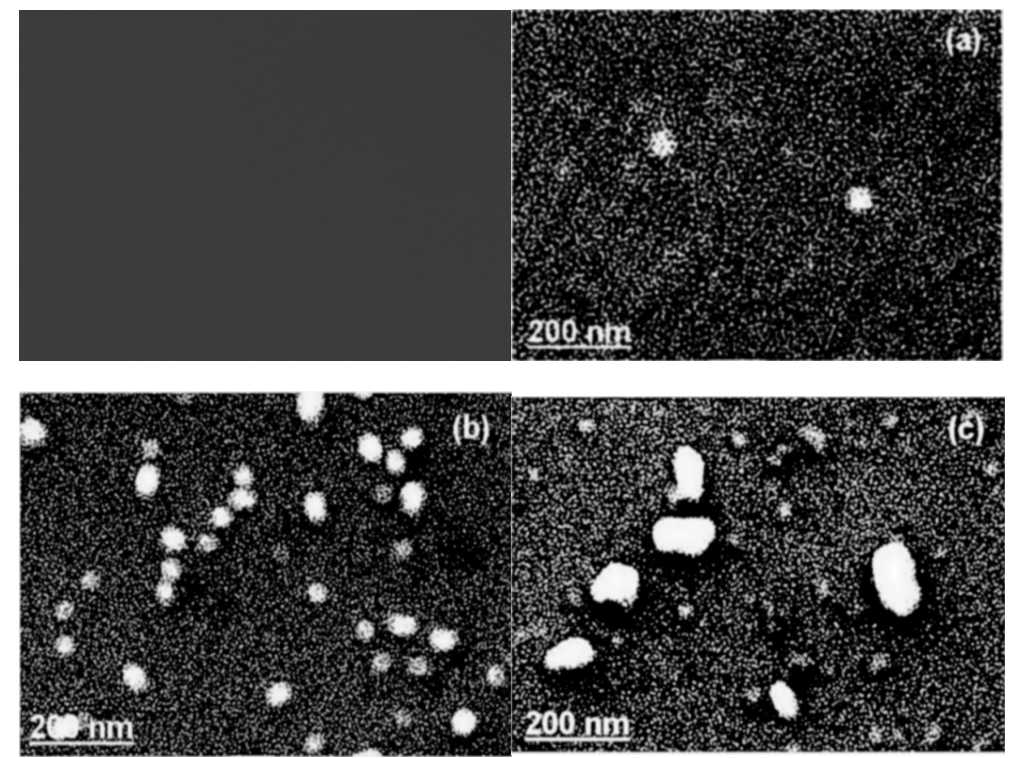

Figure3. SEM Surface Morphology Images of the $\mathrm{TiO}_{2}$ Thin Films Undoped and Doped with $\mathrm{Pb}(\mathbf{a}-\mathbf{c})$ Obtained at Various Annealing Temperature: (a) $400^{\circ} \mathrm{C}$, (b) $450^{\circ} \mathrm{C}$, (c) $500^{\circ} \mathrm{C}$. 
AFM surface imaging analysis investigation confirmed the crystallization of the films due to annealing temperature. It can be observed from Fig.4 (a, b, c) a large spherical grain more uniform are display not only at the surface morphology but are distributed along the thickness of the film; however, as the annealing temperature increased the grains tend to agglomerate in preferred orientation. The computed values of microstructural parameters, given in Table 2, were calculated for different temperatures of annealing with the same thickness. Thus, increasing the annealing temperature from 400 to $500{ }^{\circ} \mathrm{C}$ increase slowly the surface roughness RMS (Root Mean Square) from 1.05 to $2.67 \mathrm{~nm}$ respectively. On the other hand, the grain sizes are ranged from 20.05 to $100.1 \mathrm{~nm}$. The increase in the roughness is due to the increase in the grain size. The well-defined crystallinity and particle size of doped $\mathrm{TiO}_{2}$ was confirmed by the good correlation with XRD and SEM analysis.
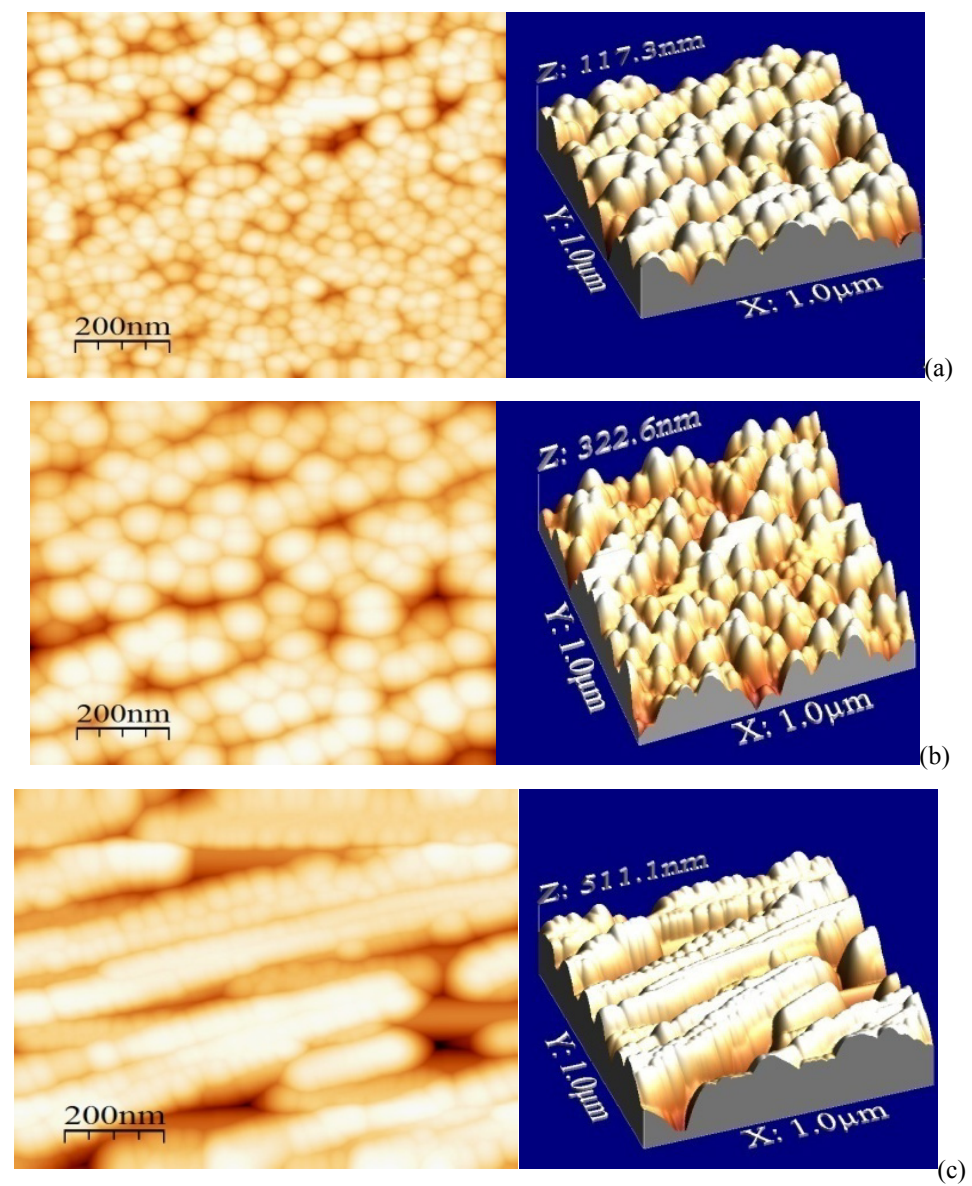

Figure 4. $\mathrm{AFM}$ images of the $\mathrm{TiO}_{2}$ thin films doped with $\mathrm{Pb}$ obtained at various annealing temperature: (a) $400^{\circ} \mathrm{C}$, (b) $450^{\circ} \mathrm{C}$, (c) $500^{\circ} \mathrm{C}$.

Table.2. The influence of the annealing temperature on $\mathrm{Pb}$-doped $\mathrm{TiO}_{2}$ film average grain size, roughness and optical band gap obtained by reflectance and SE analyses.

\begin{tabular}{ccccc}
\hline \multirow{2}{*}{$\left(^{\circ} \mathbf{C}\right)$} & \multicolumn{2}{c}{ AFM analysis } & UV-vis analysis & SE analysis \\
\cline { 2 - 5 } & $\begin{array}{c}\text { Average grain } \\
\text { size }(\mathrm{nm})\end{array}$ & $\begin{array}{c}\text { RMS } \\
(\mathrm{nm})\end{array}$ & $\begin{array}{c}\text { Optical band } \\
\text { gap }(\mathrm{eV})\end{array}$ & $\begin{array}{c}\text { Optical band } \\
\text { gap }(\mathrm{eV})\end{array}$ \\
$\mathbf{4 0 0}$ & 20,05 & 1,05 & 2,59 & 2,60 \\
$\mathbf{4 5 0}$ & 27,98 & 1,82 & 2,48 & 2,38 \\
$\mathbf{5 0 0}$ & 100,1 & 2,67 & 2,01 & 1,98 \\
\hline
\end{tabular}




\subsection{Optical properties}

\subsubsection{UV absorption analysis}

Fig.5 displays diffused scattering UV-VIS transmittance spectra of undoped and $\mathrm{Pb}$-doped $\mathrm{TiO}_{2}$ thin films, for different annealing temperatures and different dipping numbers in the wavelength range 300-800 $\mathrm{nm}$. Transmission of titanium oxide thin films decreases with the increase of annealing temperature and with the number of dipping. Optical transmittance higher than $95 \%$ in the visible region of spectrum is obtained for all films. The transmission of the titanium oxide thin films in the visible region, increase with the $\mathrm{Pb}$ doped. This can be ascribed to the formation of larger particles on the surface of $\mathrm{Pb}$-doped $\mathrm{TiO}_{2}$ thin films [48].

The bands caused by the interference color of the film appeared in the wavelength range of $350-800 \mathrm{~nm}$. The amplitude of interference spectra also increases with increasing annealing temperature and number of dipping, due to the increase in the refractive index of thin films. A slight shift of transmission curves to higher wavelengths is observed for curves of doped thin films (Fig.5) in comparison with those undoped.

The refractive index of $\mathrm{TiO}_{2}$ thin films was calculated from measured UV-VIS transmittance spectrum. Evaluation method used in this work is based on the analysis of UV-VIS transmittance spectrum of a weakly absorbing film deposited on a non-absorbing substrate. The refractive index $n(\lambda)$ over the spectral range is calculated by using the envelopes that are fitted to the measured extreme [49]:

$$
\begin{array}{r}
n(\lambda)=\sqrt{s+\sqrt{s^{2}-n_{0}^{2}(\lambda) n_{s}^{2}(\lambda)}} \quad(B .2) \\
s=\frac{1}{2}\left(n_{0}^{2}(\lambda)+n_{s}^{2}(\lambda)\right)+2 n_{0} n_{s} \frac{T_{\max }(\lambda)-T_{\min }(\lambda)}{T_{\max }(\lambda) \times T_{\min }(\lambda)}
\end{array}
$$

Where $\mathrm{n}_{0}$ is the refractive index of air, $\mathrm{n}_{\mathrm{s}}$ is the refractive index of the film, $T_{\max }$ is the maximum envelope, and $\mathrm{T}_{\text {min }}$ is the minimum envelope. The thickness of the films was adjusted to provide the best fits to the measured spectra. In this study, all the deposited films are assumed to be homogeneous. The porosity of the thin films is calculated using the following equation [50]:

$$
\rho=\left(1-\frac{n^{2}-1}{n_{d}^{2}-1}\right) 100(\%)
$$

Where $n_{\mathrm{d}}$ is refractive index of pore-free anatase $\left(n_{\mathrm{d}}=2.52\right)$ [51], and $n$ is the refractive index of porous thin films. The results of the computed refractive index $(n)$ and porosity $(\rho)$ are reported in Table.3. It is noted that the refractive index of thin films of doped titanium oxide increases with increasing annealing temperature and number of dipping, the porosity decreases. The increase in refractive index with annealing temperature is due to densification of the film [52].Moreover, this results correlated to phase transition (anatase, anatase-brookite), which increases grain sizes and/or pore destruction in films due to the increase of annealing temperature and number of dipping $[11,40]$.

Table.3. Variation of Refractive Index $(n)$ and Porosity $(\rho)$ for Different Annealing Temperatures and Different Number of Layers.

\begin{tabular}{ccccccc}
\hline \multirow{2}{*}{$\mathbf{T}\left({ }^{\circ} \mathbf{C}\right)$} & \multicolumn{2}{c}{$\mathbf{4}$ Layers } & \multicolumn{2}{c}{$\mathbf{6}$ Layers } & \multicolumn{2}{c}{$\mathbf{8}$ Layers } \\
\cline { 2 - 7 } & $\mathrm{n}$ & Porosity & $\mathrm{n}$ & Porosity & $\mathrm{n}$ & Porosity \\
$\mathbf{4 0 0}$ & 2,27 & 12,37 & 2,49 & 1,48 & 2,67 & 9,40 \\
$\mathbf{4 5 0}$ & 2,59 & 3,46 & 2,55 & 1,49 & 2,65 & 6,43 \\
$\mathbf{5 0 0}$ & 2,63 & 5,44 & 2,64 & 5,94 & 2,71 & 7,42 \\
\hline
\end{tabular}

\subsubsection{Reflectance}

The reflectance spectrum recorded for the $\mathrm{Pb}$-doped $\mathrm{TiO}_{2}$ thin films for the annealing temperature of $400^{\circ} \mathrm{C}, 450^{\circ} \mathrm{C}$ and $500^{\circ} \mathrm{C}$ are shown in Fig.6. The reflectance reaches $65 \%$ in the visible region. Increasing annealing temperature causes a decrease in the thickness and the reflectance percentage. This corresponds to the decrease of the film refractive index. The band gap of the samples was determined by the equation [53]:

$$
E_{g}=\frac{1239.8}{\lambda}
$$

Where $E_{g}$ is the optical band gap $(\mathrm{eV})$ and $\lambda(\mathrm{nm})$ is the wavelength of the absorption edge in the spectrum. The reflectance analysis shows that the optical band gap decreases from $2.59 \mathrm{eV}$ to $2.01 \mathrm{eV}$ by increasing the annealing temperature from 400 to $500^{\circ} \mathrm{C}$. The decrease of the $\mathrm{TiO}_{2}$ optical band gap with annealing temperature may be due to the change of the film density and the increase in grain size. The reduction in band gap is favorable for the enhanced photocatalytic application of $\mathrm{TiO}_{2}$ in the visible

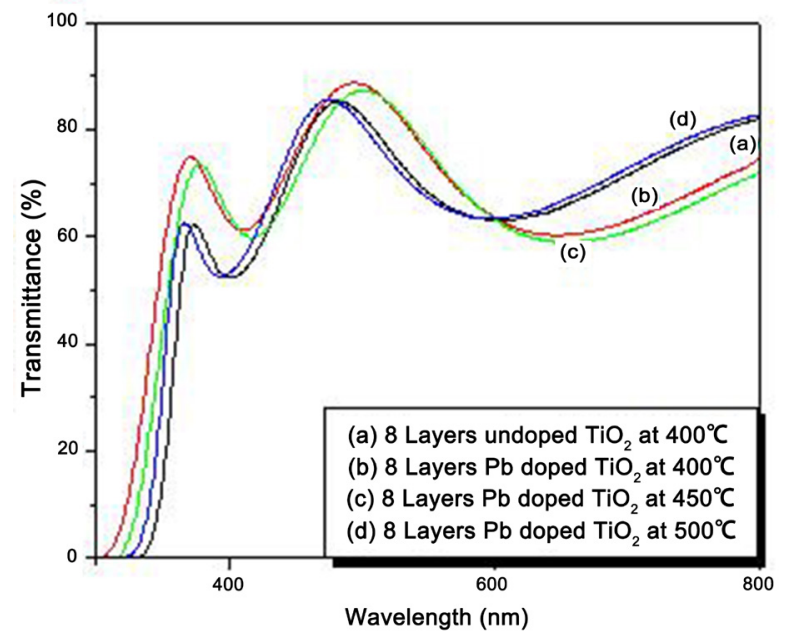

Figure 5. Transmittance Spectra of Thin Films $\mathrm{TiO}_{2}$ undoped and Doped with $\mathrm{Pb}$ Thin Films for Different Annealing Temperature $\left(400-500^{\circ} \mathrm{C}\right)$. 


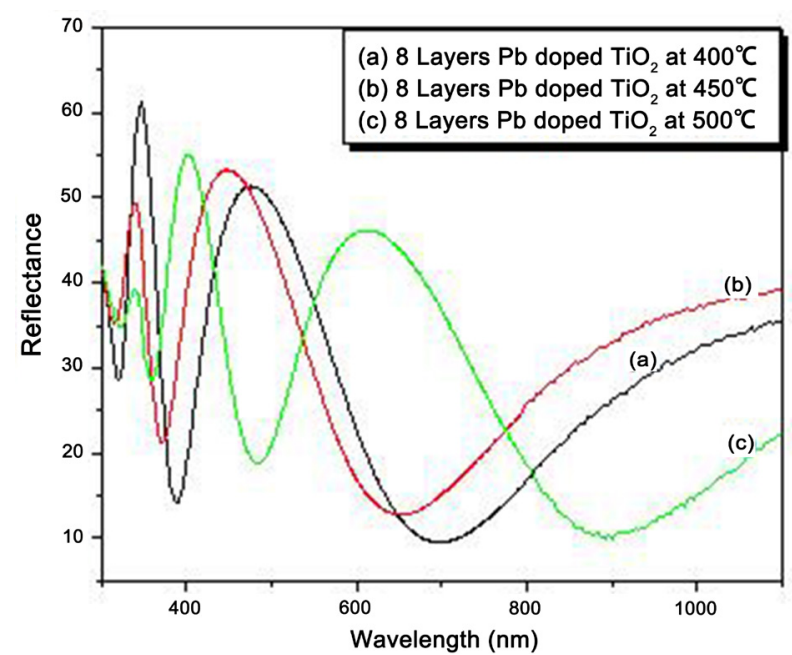

Figure 6. Reflectance spectra of the $\mathrm{TiO}_{2}$ thin films doped with $\mathrm{Pb}$ obtained at annealing temperatures of 400 (a), $450^{\circ} \mathrm{C}$ (b) and $500^{\circ} \mathrm{C}$ (c).

(a)

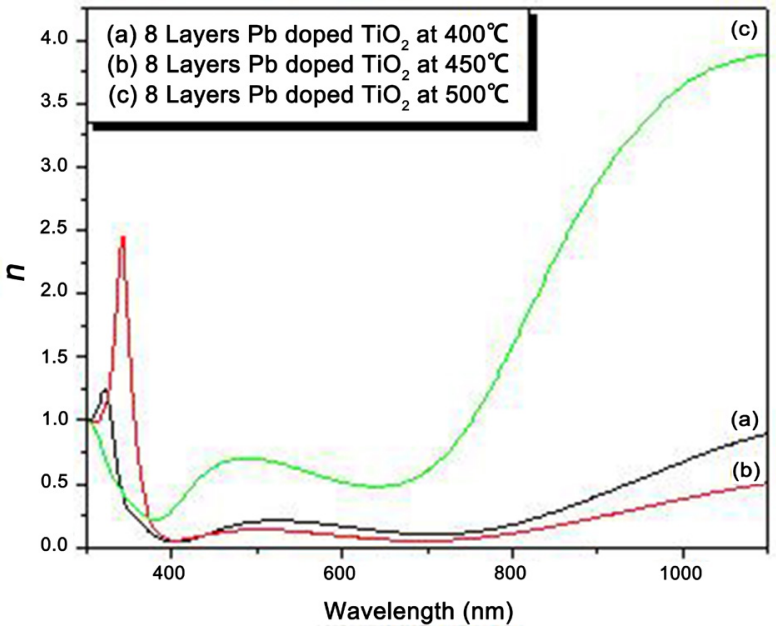

(b)

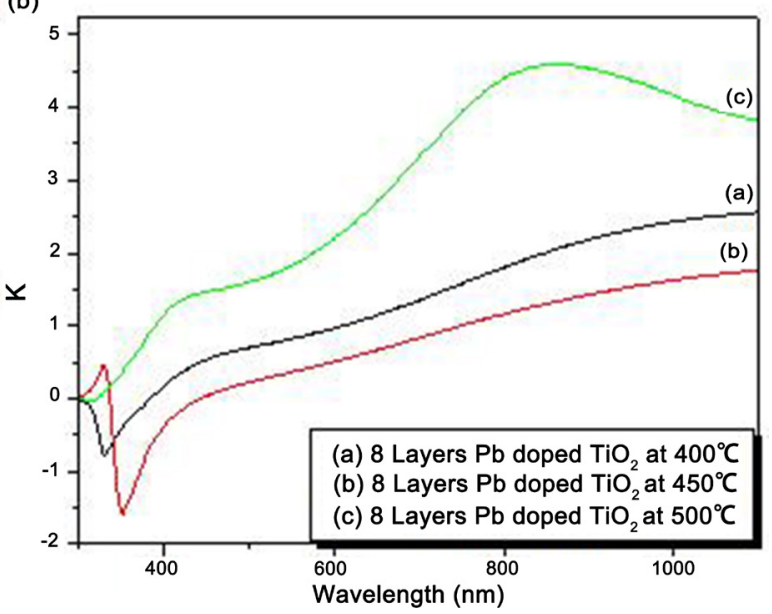

Figure7. Refractive index (a) and extinction coefficient (b) as a function of wavelength of $\mathrm{Pb}$ doped $\mathrm{TiO}_{2}$ films annealed at $400^{\circ} \mathrm{C}$, $450^{\circ} \mathrm{C}$ and $500^{\circ} \mathrm{C}$

\subsubsection{Spectroscopic Ellipsometry}

Fig.7 (a) and (b) show the results of the ellipsometric analysis in terms of refractive index (n) and extinction coefficient $(\mathrm{k})$, as a function of wavelength (300-1000 $\mathrm{nm}$ ), for 5 at. $\% \mathrm{~Pb}$ doped $\mathrm{TiO}_{2}$ samples annealed at 400 , 450 and $500^{\circ} \mathrm{C}$ for 2 hours. It can be clearly see that the refractive index of the $\mathrm{Pb}$ doped $\mathrm{TiO}_{2}$ thin films increases with increasing annealing temperature and wavelength. Whereas, S.K. Sharma et al. [54] reported that the refractive index decreased with the increase of wavelength and annealing temperature. In Table. 2 we listed the SE obtained $\mathrm{E}_{\mathrm{g}}$ values; the optical band gap is in good agreement with the reflectance results. As can be seen, we can confirm using another optical technique (SE) that the annealing affects the optical band gap, which is found to decrease by increasing the temperature from $2,60 \mathrm{eV}$ to $1,98 \mathrm{eV}$. These can be explaining by effect of $\mathrm{Pb}$ dopant in $\mathrm{TiO}_{2}$ thin film compared with the undoped $\mathrm{TiO}_{2}[40]$. Theoretical Krishna et al. [21] reveals that we can reduce the band gap of $\mathrm{TiO}_{2}$ by doping with $\mathrm{Pb}$. These results are consistent with the reflectance results. The ellipsometric analysis also allows as well finding the layer thicknesses of $\mathrm{Pb}$ doped $\mathrm{TiO}_{2}$ samples. The thicknesses change from $117,3 \mathrm{~nm}$ to $511,1 \mathrm{~nm}$ for the sample annealed between $400^{\circ} \mathrm{C}$ and $500^{\circ} \mathrm{C}$ for 2 hours.

\subsubsection{Photoluminescence spectroscopy}

Fig. 8 shows Photoluminescence (PL) spectra of $\mathrm{Pb}$-doped $\mathrm{TiO}_{2}$ thin films, annealed at different temperatures $\left(400^{\circ} \mathrm{C}, 450^{\circ} \mathrm{C}\right.$ and $\left.500^{\circ} \mathrm{C}\right)$. An intense greenish yellow luminescence is observed in the visible region, and doping with 5 at. \% of lead increases peak intensity. PL spectra of our samples exhibits three peaks at $405 \mathrm{~nm}, 430 \mathrm{~nm}$, and $480 \mathrm{~nm}$, demonstrating that the lead as a dopant give rise to new PL phenomena.

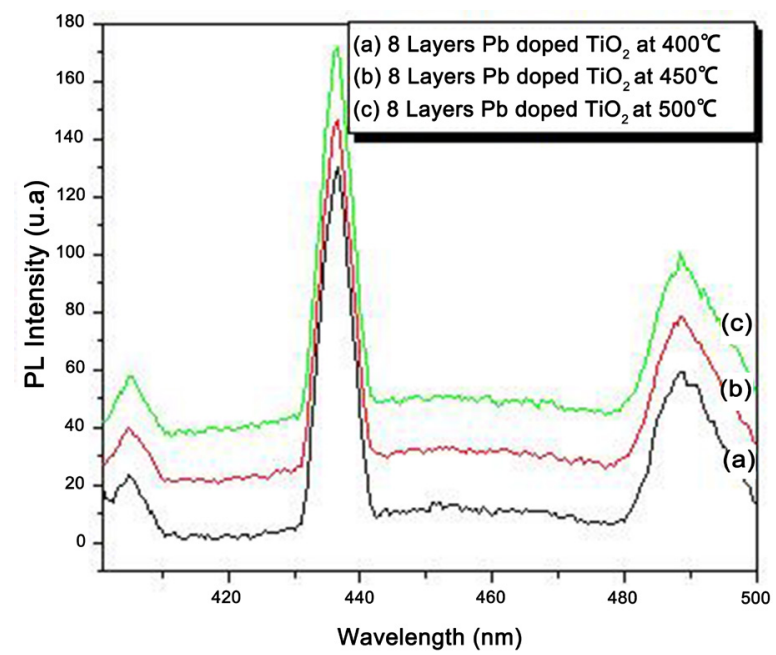

Figure 8. Photoluminescence spectra of the $\mathrm{TiO}_{2}$ thin films doped with $\mathrm{Pb}$ obtained at annealing temperatures of $400(\mathrm{a}), 450^{\circ} \mathrm{C}(\mathrm{b})$ and $500^{\circ} \mathrm{C}$ (c).

The peak at $405 \mathrm{~nm}$ may be attributed to the impurity or extrinsic self-trapping effect, as also observed earlier [55, 56] in $\mathrm{La}, \mathrm{Cu}$, In and $\mathrm{Ce}$ doped $\mathrm{TiO}_{2}$. The sharp emission 
peak at $430 \mathrm{~nm}$ can be seen. It is ascribed well to the transitions to the ${ }^{1} \mathrm{P}_{1}$ level of $\mathrm{Pb}$ ions, the doping with $\mathrm{Pb}$ introduction a new defect sites in $\mathrm{TiO}_{2}$ that enhance non-radiative recombination of the excited electrons [57]. Theprominent peak at $480 \mathrm{~nm}$ can be attributed to the oxygen vacancies. Addition of $\mathrm{Pb}$ shifts the peak intense towards to higher wavelengths (lower energy), further supports to the lowering of the band gap of $\mathrm{TiO}_{2}$ with $\mathrm{Pb}$ doping. Also, the PL emission intensity deduces a continuous increase in the luminescence intensity as the temperature increases. The increase in emission intensity with annealing temperature may be due to the presence of mixed phase at high temperatures, which confirmed by XRD and SEM analyses.

\section{Conclusions}

In this study, structural and optical properties of $\mathrm{Pb}$-doped $\mathrm{TiO} 2$ thin films, prepared by sol-gel method using dip-coating technique were studied which were successfully prepared on glass and silicon substrates. XRD and Raman spectroscopy results show that doped thin films crystallize in both anatase and brookite phases. The crystallite size has been increased with increasing of annealing temperature from 400 to $500^{\circ} \mathrm{C}$. SEM and AFM observations of doped thin films reveal nanoporous structure with crystallite size in the range of $20 \mathrm{~nm}$ to 100 $\mathrm{nm}$ in comparison with those undoped. Analysis of UVVIS transmission spectra shows that the doped thin films are transparent in the visible range and opaque in the UV region. The complex index and the optical band gap $\left(\mathrm{E}_{\mathrm{g}}\right)$ of the films were determined by the spectroscopic ellipsometry analysis. We have found that spectroscopic ellipsometry and reflectance are in good agreement. The refractive index increases with increasing the annealing temperature and wavelength. While, the porosity decreases, energy band gap of $\mathrm{Pb}$-doped $\mathrm{TiO}_{2}$ films decrease owing to an increase in annealing temperatures. PL measurement shows also a high emission with a slight shift to higher wavelengths (lower energy), which supports the lowering of the band gap of $\mathrm{Pb}$-doped $\mathrm{TiO}_{2}$. In this study; we have carefully prepared optical materials of $5 \%$ $\mathrm{Pb}$-doped $\mathrm{TiO}_{2}$ thin films.

\section{REFERENCES}

[1] Hara K, Hariguchi T, Kinoshita T, Sayama K, Arakawa H ,J Sol Energy Mater 70,151,2001.

[2] R. Mechiakh, F. Meriche, R. Kremer, B. Boudine, A. Boudrioua, Opt. Mater.30,645,2007.

[3] Natarajan C, Nogami G ,J Electrochem Soc 143,1547,1996.

[4] Yu J, Zhao X, Zhao Q ,J Mater Chem Phys 69-25,2001.
[5] Y. Paz, A. Heller, J. Mater. Res. 12,2759,1997.

[6] C. Legrand-Buscema, C. Malibert, S. Bach, Thin Solid Films 418,79,2002.

[7] S.-J. Tsai, S. Cheng, Catal. Today 33,227,1997.

[8] H.P. Maruska, A.K. Ghosh, Sol. Energy 20,443,1978.

[9] Wang C, Xu BQ, Wang XM, Zhao JC,J Solid State Chem $178,3500,2005$.

[10] Hu C, Tang YC, Yu JC, Wong PK ,J Photocatal Appl Catal B Environ 40,131,2003.

[11] H. Bensouyad, D. Adnane , H. Dehdouh ,B. Toubal ,M. Brahimi , H. Sedrati ,R. Bensaha, J Sol-Gel Sci Technol $59,546,552,2011$.

[12] Bandara J, Hadapangoda CC, Jayasekera WG ,J Appl Catal B Environ 50,83,2004.

[13] H.Bensouyad, H.Sedrati, H.Dehdouh, M.Brahimi, F.Abbas ,H. Akkari, R.Bensaha ,J Thin Solid Films $519,96,2010$.

[14] S. Daniele, R. Papiernik, L.G. Hubert-Pfalzgraf, S. Jagner, M. Hikansson,Inorg. Chem. 34,628,1995.

[15] L.G. Hubert-Pfalzgraf, S. Daniele, R. Papiernik, M.C. Massiani, B.Septe, J. Mater. Chem. 7 (5),753,1997.

[16] M.C. Wang, H.J. Lin, T.S. Yang, J.Alloys Compd. $473,394,2009$.

[17] Zhang W, Zhu S, Li Y, Wang F,J Vacuum 82,328,2008.

[18] L. Madler, W.J. Stark, S.E. Pratsinis, J. Mater. Res. $18,115-120,2003$.

[19] S. Sen, S. Mahanty, S. Roy, O. Heintz, S. Bourgeois, D. Chaumont, Thin Solid Films 474, 2005.

[20] E. Sato, Y. Huang, M. Kosec, A. Bell, N. Setter, Appl. Phys.Lett. 65,2678,1994.

[21] K. M. Krishna, Md. M-ur-Rahman, T.Miki, T. Soga, K. Igarashi, S. Tanemura , M. Umeno. Applied Surface Science $113 / 114,149-154,1997$.

[22] S.D. Cheng, C.H. Kam, Y. Zhou, W.X. Que, Y.L. Lam, Y.C. Chan, W.S. Ganb 245.Thin Solid Films 375,109-113,2000.

[23] [23] X. Zeng, Y.Liu, X. Wang, W. Yin, L. Wang, H. Guo, Materials Chemistry and Physics 77,209-214(2002).

[24] R. Thomas, D.C. Dube, Jpn. J. Appl. Phys. Pt.136,7337,1997.

[25] C.J. Lu, H.M. Shen, J.S. Zhu, Y.N. Wang, J. Phys. D: Appl. Phys. 30,2338,1997.

[26] W.-z. Zhang, T. Zhang, W. Yin, G.-y. Cao, Chin. J. Chem. Phys. 20,95,2007.

[27] D. Bhattacharyya, N.K. Sahoo, S. Thakur, N.C. Das, Thin Solid Films 360,96,2000.

[28] E. Gyorgy, G. Socol, E. Axente, I.N. Mihailescu, C. Ducu, S. Ciuca, Appl. Surf. Sci.247,429,2005.

[29] M. Stamate, G.I. Rusu, I. Vascan, SPIE, vol. 
$3405,951-954,1998$.

[30] J. Medina-Valtierra, M.S. Cardenas, C.F. Reyes, S. Calixto, J. Mex. Chem. Soc. 50,8,2006.

[31] K.K. Saini, S.D. Sharma, Chanderkant, M. Kar, D. Singh, C.P. Sharma, J. Non-Cryst.Solids 353,2469,2007.

[32] L.Lan, A.Montenero, G.Gnappi, E.Dradi, J.Mater.Sci.30,3137,1995.

[33] S.J. Milne, S.H. Pyke, J. Am. Ceram. Soc. 74,1407,1991.

[34] N.J. Phillips, M.L. Calzada, S.J. Milne, J. Non-Cryst. Solids $147,285,1992$.

[35] U.Selvaraj,A.V.Prasadarao S.Komarneni,Mater.Lett.20,71,1994.

[36] M.M. Rahman, T. Miki, K.M. Krishna, T. Soga, K. Igarashi, S.Tanemura, M. Umeno, Mater. Sci. Eng. B41 ,67,1996.

[37] S.L. Miller, P.J. McWhorter,J. Appl. Phys 72,5999,1992.

[38] A. Chin, M.Y. Yang, C.L. Sun, S.Y. Chen, IEEE Electron. Dev. Lett. 22 (7),336,2001.

[39] S.D. Chen, Y. Zhou, C.H. Kam, X.Q. Han, W.X. Que, Y.L. Lam,Y.C. Chan, J.T. Oh, W.S. Gan, Mater. Lett. $44,125,2000$.

[40] R. Mechiakh, R. Bensaha, C.R. Phys.7,464,2006.

[41] R. Mechiakh, F. Meriche , R. Kremer , R. Bensaha , B. Boudine , A. Boudrioua , Optical Materials 30,645651,2007 .

[42] B.D. Cullity, Elements of X-ray Diffraction, 2nd edition, Addison-Wesley, 1978.

[43] M.Z. Hu, P. Lai, M.S. Bhuiya, C. Tsouris, B. Gu, M. Paranthaman, J. Gabitto, L. Harrison, J. Mater. Sci. 44 2820-2827,2009.
[44] P.P. Lottici, D. Bersani, M. Braghini, A. Montenero, J. Mater. Sci. 28,177,1993.

[45] Y. Djaoued, S. Badilescu, Ashrit, D. Bersani, P.P. Lottici, J. Robichaud, J. Sol-Gel Sci.Technol. 24,255,2002.

[46] C.Y. Xu, P.X. Zhang, L. Yan, J. Raman Spectrosc. 32 ,862865,2001

[47] A. Pottier, S. Cassaignon, C. Chaneac, F. Villain, E. Tronc, J.P. Jolivet, J. Mater. Chem. 13,877-882,2003.

[48] S.H. Oh, D.J. Kim, S.H. Hahn, E.J. Kim, Mater. Lett. $57,4151,2003$.

[49] J.C. Manifacier, J. Gasiot, J.P. Fillard, J. Phys. E $9,1002,1976$.

[50] B.E. Yoldas, P.W. Partlow, Thin Solid Films 129,1,1985.

[51] W.D. Kingery, H.K. Bowen, D.R. Uhlmann, Introduction to Ceramics, Wiley, NY,1976.

[52] K. Narasimha Rao, Bull. Mater. Sci. 26,239,2003.

[53] B. Oregan, M. Gratezl, Nature 353,737,1991.

[54] S.K. Sharma, M. Vishwas, K.N. Rao, S. Mohan, D.S. Reddy, K.V.A. Gowda, J. Alloys.Compd. 471,244,2009.

[55] Liqiang, J., Zhihua, S., Fulong, Y., Baiqi, W., Baifu, X., Honggang, F. Sci. China, Ser. B: Chem. 49,43454350,2006 .

[56] H. Tang, H. Berger, P.E. Schmid, F. Levy, G. Burri, Solid State Commun. 87,847,1993).

[57] H.F. Folkerts, F. Ghianni, G. Blasse, J. Phys. Chem. Solids $57,1659,1996)$ 